\title{
USTAWA ANTYLICHWIARSKA A ZMIANY NA RYNKU INSTYTUCJI POŻYCZKOWYCH - WYBRANE ZAGADNIENIA
}

\section{(część 2)}

\begin{abstract}
Artykuł prezentuje analizę skutków wejścia w życie art. 7 pkt 4 ustawy z dnia 5 sierpnia 2015 r. o zmianie ustawy o nadzorze nad rynkiem finansowym i niektórych innych ustaw. Deklarowanym ratio legis tej zmiany było wprowadzenie limitu opłat tzw. windykacyjnych (art. 33a u.k.k.) i tym samym zwiększenie poziomu ochrony konsumentów korzystających z usług instytucji finansowych udzielających pożyczek pozabankowych. Instytucje pożyczkowe przed wejściem w życie wspominanego art. 33a u.k.k. na podstawie art. 30 ust. 1 pkt 11 u.k.k. odwołującego się do zasady swobody umów pobierały od konsumentów opłaty i prowizje z tytułu zaległości w spłacie pożyczki w wysokości najczęściej znacznie przekraczającej realne koszty windykacyjne. Co więcej, powołany przepis art. 30 ust. 1 pkt 11 u.k.k. nie chronił też konsumentów przed obchodzeniem przez instytucje pożyczkowe przepisów o maksymalnych odsetkach za opóźnienie ( $481 \S 2{ }^{1}$ k.c.).

Wprowadzony limit opłat windykacyjnych zniwelował asymetrię między stronami umów o pozabankowe pożyczki. Dodatkowo konsumenci w przypadku wszczynania przez instytucje pożyczkowe postępowań sądowych lub pozasądowych o zaległe należności zyskali pewność co do prawa w zakresie ujednolicenia wykładni przepisów dotyczących wysokości opłat z tytułu dochodzonych należności.

Ocena skutków wejścia w życie z dniem 11 marca 2016 r. art. 33a u.k.k. przeprowadzona została przy wykorzystaniu metody badawczej tzw. kompletu normatywnego. Niniejszy artykuł stanowi drugą część omówienia zakreślonej problematyki badawczej i obejmuje: rekonstrukcję powiązań pomiędzy normami formalnymi i normami nieformalnymi, weryfikację postawionych hipotez badawczych, ocenę charakteru presji na formalizację badanej instytucji
\end{abstract}

\footnotetext{
${ }^{1}$ Dr Katarzyna Kurzępa-Dedo, Katedra Nauk o Administracji, Wyższa Szkoła Informatyki i Zarządzania z siedzibą w Rzeszowie, ul. H. Sucharskiego 2, 35-225 Rzeszów, autor korespondencyjny; e-mail: kkurzepa@wsiz.rzeszow.pl.

Katarzyna Kurzępa-Dedo, PhD, Department of Administration Sciences, University of Information Technology and Management based in Rzeszów, ul. H. Sucharskiego 2, 35-225 Rzeszów, correspondent author; e-mail: kkurzepa@wsiz.rzeszow.pl.

2 Dr Agata Gemzik-Salwach, Katedra Finansów, Wyższa Szkoła Informatyki i Zarządzania z siedzibą w Rzeszowie, ul. H. Sucharskiego 2, 35-225 Rzeszów; e-mail: agemzik@wsiz.rzeszow.pl. Agata Gemzik-Salwach, PhD, Department of Finance, University of Information Technology and Management based in Rzeszów, ul. H. Sucharskiego 2, 35-225 Rzeszów; e-mail: agemzik@wsiz. rzeszow.pl.
} 
i społeczno-gospodarczych efektów jej oddziaływania oraz prognozowanie i formułowanie zaleceń badawczych.

Słowa kluczowe: limit opłat windykacyjnych, zaległości w spłacie pożyczki, instytucje pożyczkowe, konsumenci.

\section{WPROWADZENIE}

Niniejszy artykuł stanowi kontynuację analizy instytucjonalnej art. 7 pkt 4 ustawy z dnia 5 sierpnia 2015 r. o zmianie ustawy o nadzorze nad rynkiem finansowym i niektórych innych ustaw ${ }^{3}$ i obejmuje: rekonstrukcję powiązań pomiędzy normami formalnymi i normami nieformalnymi, weryfikację postawionych hipotez badawczych, ocenę charakteru presji na formalizację badanej instytucji i społeczno-gospodarczych efektów jej oddziaływania oraz prognozowanie i formułowanie zaleceń badawczych. Ocena skutków wejścia w życie z dniem 11 marca 2016 r. art. 33a uk.k. przeprowadzona zostanie przy wykorzystaniu metody badawczej tzw. kompletu normatywnego ${ }^{4}$.

\section{REKONSTRUKCJA POWIĄZAŃ POMIĘDZY NORMAMI FORMALNYMI I NORMAMI NIEFORMALNYMI}

Schemat działania wynikający z przedmiotowej regulacji tworzą głównie rozwiązania sformalizowane przepisami prawa powszechnie obowiązującego, natomiast uzupełniają go normy wewnętrzne związane $\mathrm{z}$ funkcjonowaniem instytucji pożyczkowych oraz tzw. niesformalizowane reguły działania determinujące zachowania konsumentów i instytucji pożyczkowych (ekonomiczne i pozaekonomiczne).

\subsection{Normy prawa powszechnie obowiązującego}

Zaliczyć do nich należy następujące regulacje:

a) w zakresie bezpośrednim związanym z materią analizowanej ustawy:

- ustawę z dnia 12 maja 2011 r. o kredycie konsumenckim ${ }^{5}$,

- ustawę z dnia 23 kwietnia 1964 r. Kodeks cywilny6

- ustawę z dnia 5 sierpnia 2015 r. o zmianie ustawy o nadzorze nad rynkiem finansowym oraz niektórych innych ustaw,

b) dodatkowo w zakresie czynności prawnych dokonywanych między klientami a instytucjami pożyczkowymi:

- ustawę z dn. 17 listopada 1964 r. Kodeks postępowania cywilnego ${ }^{7}$,

${ }^{3}$ Ustawa z 5 sierpnia 2015 r. o zmianie ustawy o nadzorze nad rynkiem finansowym oraz niektórych innych ustaw (Dz.U. z 2015 r., poz. 1357).

${ }^{4}$ Szerzej zobacz na temat metody badawczej: P. Chmielnicki (red.), Pochodzenie, tworzenie i efektywność prawa, Warszawa 2014 oraz http://fontes.wsiz.pl/badania-naukowe/metodyka (dostęp: 30.04.2018 r.).

${ }^{5}$ Ustawa z dnia 12 maja 2011 r. o kredycie konsumenckim (tekst jednolity Dz.U. z 2018 r., poz. 993 ze zm.), dalej cyt. jako u.k.k.

${ }^{6}$ Ustawa z dnia 23 kwietnia 1964 r. kodeks cywilny (t.j. Dz.U. z 2018 r., poz. 1025, ze zm.), dalej cyt. jako k.c.

${ }^{7}$ Ustawa z dnia 17 listopada 1964 r. kodeks postępowania cywilnego (tj. Dz.U. z 2018 r., poz. 155). 
- ustawę z dn. 28 lipca 2005 r. o kosztach sądowych w sprawach cywilnych ${ }^{8}$,

- ustawę z dn. 29 sierpnia 1997r. o komornikach sądowych i egzekucji ${ }^{9}$.

\subsection{Sformalizowane normy wewnętrzne}

W przypadku instytucji pożyczkowych sformalizowane normy wewnętrzne ujęte są w formie regulaminów, tabeli opłat, wzorów umów i dotyczą relacji tych instytucji z klientami w zakresie świadczonych usług finansowych oraz wewnętrznych procedur obowiązujących pracowników przedmiotowych instytucji, a związanych z obsługą klientów.

\subsection{Niesformalizowane reguły działania}

Zaliczyć do nich należy przede wszystkim reguły ekonomiczne (np. ocena kosztów, ryzyka, w tym też ryzyka kredytowego, sytuacji na rynku instytucji pożyczkowych) składające się na proces decyzyjny konsumentów, ale i instytucji pożyczkowych w zakresie udzielanych pożyczek. Nie bez znaczenia jest również minimalizacja kosztów, szybkość odzyskania należności, dyskrecja. Te czynniki ekonomicznie i pozaekonomicznie będą determinować wybór postępowania zmierzającego do wyegzekwowania przez stronę (instytucję pożyczkową) wierzytelności w związku z niewykonaniem lub nienależytym wykonaniem umowy przez drugą stronę (konsumenta).

\subsection{Rekonstrukcja powiązań pomiędzy normami formalnymi i normami niesformalizowanymi}

Czynności przedstawione poniżej są konsekwencją zawierania umów pomiędzy instytucjami pożyczkowymi a klientami, którymi najczęściej są konsumenci. Poniższe rozważania będą prowadzone wyłącznie $\mathrm{w}$ odniesieniu do niewykonania umowy przez konsumenta czyli ciążącego na nim obowiązku spłaty pożyczki w terminie wynikającym z umowy (art. 471 k.c. w zw. art. 30 ust. 1 pkt 11 u.k.k.). ${ }^{10}$

Instytucji pożyczkowej jako wierzycielowi w przedmiotowym stosunku obligacyjnym przysługują różne możliwości w zakresie dochodzenia ochrony swoich praw. Chodzi zarówno o podjęcie działań w celu skierowania danej sprawy na drogę postępowania sądowego, jak również skorzystanie z tzw. alternatywnych sposobów rozwiązania sporu (np. arbitraż, mediacja), które pozwolą uniknąć nierzadko długotrwałego i kosztownego procedowania. Rozstrzygające znaczenie przy wyborze sposobu wyegzekwowania należności mają: rodzaj pożyczki i sposób ustalania - zgodnie z art. 33a u.k.k. - wysokości opłat i odsetek w przypadku zaległości jej spłacie. Nie bez znaczenia są również czynniki nieformalne, takie jak szybkość oraz dyskrecja postępowania (czynniki pozaekonomiczne) i minimalizacja kosztów (czynniki ekonomiczne).

Niezależnie od wyboru sposobu dochodzenia roszczeń kluczowe jest w pierwszej kolejności ustalenie przez instytucję pożyczkową wysokości - zgodnie z limitem wynikającym z art. 33a u.k.k. - należności powstałej w związku z opóźnieniem w spłacie pożyczki.

\footnotetext{
${ }^{8}$ Ustawa z dnia 28 lipca 2005 r. o kosztach sądowych w postępowaniach cywilnych (tj. Dz.U. z 2018 r., poz. 300 ).

9 Ustawa z dn. 29 sierpnia 1997 r. o komornikach sądowych i egzekucji (tj. Dz.U. z 2017 r., poz. 1277).

10 Szerzej zob. Z. Ofiarski, Ustawa o kredycie konsumenckim. Komentarz, Warszawa 2014 r., Wyd. LEX, art. 30 (dostęp: 19.03.2018 r.).
} 
Przedmiotowy limit ma zastosowanie w przypadku każdej umowy o pożyczkę (kredyt konsumencki), jeśli jej wartość nie przekracza, w myśl art. 3 ust. 1 u.k.k, kwoty 255550 zł albo równowartości tej kwoty w walucie innej niż waluta polska. Biorąc pod uwagę gramatyczną wykładnię art. 33a u.k.k., to ograniczenie w nim wskazane nie będzie miało zastosowania do umów wymienionych w art. 4 ust. 1 oraz ust. 2 pkt 2-4 i 6 u.k.k. czyli m.in. umowy odwróconego kredytu hipotecznego, leasingu jeśli umowa nie przewiduje obowiązku nabycia przedmiotu umowy przez konsumenta ${ }^{11}$. W piśmiennictwie postuluje się rozszerzenie zastosowania limitu opłat windykacyjnych na umowę restrukturyzacyjną opisaną w art. 4 ust. 2 pkt 5 u.k.k. ${ }^{12}$

Reguła dotycząca limitowania opłat windykacyjnych dotyczy umów, które zawarto w dniu 11 marca 2016 r., czyli w dniu wejścia w życie przepisu art. 33a u.k.k. lub później.

Jeśli instytucja pożyczkowa i konsument w treści umowy nie określili stopy odsetek za opóźnienie w spłacie należności, to wówczas należą się pożyczkodawcy tzw. odsetki ustawowe. Ich stawka, zgodnie z art. $481 \S 2$ k.c., jest sumą stopy referencyjnej Narodowego Banku Polskiego i 5,5 pkt procentowych. Natomiast maksymalna wysokość nie może przekraczać w stosunku rocznym dwukrotności wysokości odsetek ustawowych za opóźnienie (art. $481 \S 2^{1}$ k.c.) ${ }^{13}$. Zgodnie z dyspozycją wynikająca z art. 33a. u.k.k. łączna kwota należności instytucji pożyczkowej z tytułu zaległości w spłacie pożyczki przez konsumenta nie może przekraczać odsetek maksymalnych za opóźnienie naliczonych za okres opóźnienia. Przez pojęcie zaległości w spłacie kredytu należy rozumieć na tle art. 30 pkt 11 u.k.k. in fine wszelkie opłaty, prowizje, składki, kary ${ }^{14}$. Spod tego zakresu wyłączone są koszty obciążające instytucję pożyczkową na postawie przepisów prawa np. opłaty sądowe, koszty postępowania egzekucyjnego czy zastępstwa procesowego.

Z literalnego brzmienia art. 33a u.k.k. wynika, że jeśli instytucja pożyczkowa naliczyła konsumentami odsetki maksymalne od zaległej kwoty zgodnie z postanowieniami umowy, to wówczas nie może naliczyć i pobrać innych opłat związanych z zaległą należnością. W sytuacji jednak kiedy stawka naliczonych odsetek od zaległej kwoty nie przekracza wysokości odsetek maksymalnych możliwe jest naliczenie i pobranie opłat związanych z zaległą należnością w wysokości wynikającej z różnicy między wysokością odsetek maksymalnych (art. $481 \S 2^{1}$ k.c.) a wysokością naliczonych już odsetek za opóźnienie od zaległej kwoty ustalonych zgodnie z postanowieniami umowy.

Wprowadzony limit zaległości w spłacie pożyczki obowiązuje ex lege i nie ma potrzeby wskazywania na niego lub jego wysokość w treści umowy o pożyczkę. Praktyka instytucji pożyczkowych w tym zakresie jest jednak zróżnicowana. Są pożyczkodawcy, którzy wyraźnie informują $\mathrm{w}$ umowie pożyczki lub regulaminie pożyczek o limicie wynikającym z art. 33a u.k.k. ${ }^{15}$

11 Tak. T. Czach, Kredyt konsumencki. Komentarz, Warszawa 2017, Wyd. II - LEX, art. 33a (dostęp: 19.03.2018 r.).

12 Tamże, art. 33a.

${ }^{13}$ Zob. m.in. wyrok Sądu Najwyższego z dn. 6 kwietnia 2017 r., III CSK 174/2016, LEX nr 2340584 (dostęp: 19.03.2018 r.).

14 T. Czach, Kredyt konsumencki. Komentarz, Warszawa 2017, Wyd. II - LEX, art. 30 (dostęp: 19.03.2018 r.).

15 Zob. np. formularz umowy o pożyczkę ( $\$ 5$ pkt 7 i 8), którym posługuje się instytucja pożyczkowa SMSKredyt, https://www.smskredyt.pl/images/kacik-klienta/20180301Umowa_pozyczki_pienieznej_SMSKredyt.pdf, (dostęp: 20.05.2018 r.). 
Powołany przepis ma charakter semidyspozytywny, co oznacza, że może być zmieniony jedynie na korzyść konsumenta. Poza tym stosowanie jego dyspozycji następuje niezależnie od tego czy opóźnienie w spłacie należności wynika $\mathrm{z}$ winy czy też braku winy konsumenta.

Limit $\mathrm{w}$ zakresie opłat związanych $\mathrm{z}$ zaległością $\mathrm{w}$ spłacie należności wynikających z umów pożyczkowych w postępowaniach rozpoznawczych (sądowych i pozasądowych) brany jest pod uwagę z urzędu. Oznacza to, że konsument nie obowiązku wskazywania go jako zarzutu naruszenia prawa podmiotowego wynikającego z art. 33a u.k.k. Jeśli żądanie pozwu przekracza ustawowy limit, wówczas sąd powinien oddalić je w części przekroczenia ${ }^{16}$. Instytucja pożyczkowa, która pobrała od konsumenta kwoty wykraczające poza wysokość wynikającą $\mathrm{z}$ art. 33a u.k.k. uzyskała tym samym świadczenie nienależne w rozumieniu art. 410 k.c. podlegające zwrotowi w trybie art. 405 k.c. Co więcej, pobieranie przez instytucje pożyczkowe od konsumentów należności wbrew zasadzie wyrażonej w art. 33a u.k.k. stanowi praktykę naruszającą zbiorowe interesy konsumentów w rozumieniu art. 24 ust. 1 u.o.k.k. ${ }^{17}$

\section{WERYFIKACJA HIPOTEZ BADAWCZYCH}

Postawione hipotezy badawcze poddane zostały weryfikacji, która doprowadziła do następujących wniosków:

1) wprowadzenie limitu opłat windykacyjnych zwiększyło ochronę klientów instytucji pożyczkowych przed nadmiernymi, nieuzasadnionymi kosztami z tytułu nieterminowego spłacania pożyczek. Tym samym zniwelowana została asymetria między stronami umów o pozabankowe pożyczki. Dodatkowo, konsumenci w przypadku wszczynania przez instytucje pożyczkowe postępowań sądowych lub pozasądowych o zaległe należności zyskali pewność co do prawa w zakresie ujednolicenia wykładni przepisów dotyczących wysokości opłat $\mathrm{z}$ tytułu dochodzonych należności.

2) po wprowadzaniu analizowanego przepisu art. 33a u.k.k. (wejście w życie z dniem 11.03.2016 r.) oraz art. 59a u.k.k. (wejście w życie z dniem 11.10.2015 r.) sytuacja finansowa instytucji pożyczkowych uległa pogorszeniu. Trudno jest jednak jednoznacznie stwierdzić, co było przyczyną takiego stanu rzeczy - zmniejszenie zysków z tytułu opłat za opóźnienia w spłacie udzielonych pożyczek i zwiększenie kosztów własnych (art. 33a u.k.k.) czy z tytułu trudności związanych z zapewnieniem odpowiednio wysokiego kapitału zakładowego (art. 59a ust. 2 u.k.k.). Z branżowego Rejestru Firm Pożyczkowych prowadzonego przez Związek Firm Pożyczkowych wynika, że w okresie od wprowadzenia limitu należności tzw. pozaodsetkowych regulujących działalność instytucji pożyczkowych, czyli od 11 marca 2016 r. do czerwca 2016 r. 21 instytucji pożyczkowych zawiesiło swoją działalność lub nie spełniło wymogów ustawowych. Wśród tych 21 instytucji 13 zawiesiło lub zakończyło działalność, 4 nie obniżyło cen pożyczek do obowiązujących limitów, a kolejne 4 nie spełniło innych wymogów przewidzianych prawem. W wyniku tej aktualizacji w Rejestrze zostało zawieszonych łącznie 21 instytucji pożyczkowych, co stanowi ponad $17 \%$

16 T. Czach, Kredyt konsumencki. Komentarz, Warszawa 2017, wyd. II - LEX, art. 33a (dostęp: 19.03.2018 r.).

17 Ustawa z dnia 16 lutego 2007 r. o ochronie konkurencji i konsumentów (tekst jedn. Dz.U. z 2015 r., poz. 184) (dalej jako: u.o.k.k.). 
wszystkich ogólnopolskich instytucji pożyczkowych monitorowanych w rejestrze organizacji pracodawców tego rynku ${ }^{18}$.

Dodatkowo pogorszeniu uległy też nastroje wśród instytucji pożyczkowych, co było związane z wprowadzanymi regulacjami, obawami przed ich skutkami oraz widocznymi już oznakami zbliżających się trudności. Konferencja Przedsiębiorstw Finansowych w Polsce prowadziła po raz kolejny badania ankietowe, w których uczestniczyli eksperci z 11 instytucji pożyczkowych. Zadawano pytania m. in. o przewidywaną koniunkturę w sektorze instytucji pożyczkowych. Wyniki badań na koniec 2016 r. w porównaniu z badaniami za I półrocze 2016 r. wskazywały na znaczne pogorszenie się nastrojów wśród instytucji pożyczkowych, co było prawdopodobnie spowodowane wprowadzanymi regulacjami. W perspektywie kolejnych 12 miesięcy eksperci z instytucji pożyczkowych ocenili koniunkturę obojętnie - $64 \%$ wszystkich odpowiedzi to wskazania „,neutralne”. Jednocześnie po 18\% respondentów ocenia ją ,,raczej dobrze” i „raczej źle”, natomiast w I półroczu 2016 roku oprócz głosów neutralnych dominowały wskazania pozytywne, które łącznie stanowiły $45 \%$. W perspektywie od 1 do 3 lat również można zaobserwować obniżenie ocen w stosunku do poprzedniej edycji badania. Na koniec I połowy 2016 roku zdecydowanie więcej było pozytywnych przewidywań co do koniunktury w sektorze, gdzie wskazań „dobrych" i ,raczej dobrych" było aż $54 \%{ }^{19}$.

3) instytucje pożyczkowe zmieniły dotychczasowe oferty pożyczkowe. Większość produktów oferowanych przez nie miała tak ustalone parametry opłat, że nie spełniały one wymogów określonych przez nowelizację ustawy o kredycie konsumenckim w zakresie maksymalnych pozaodsetkowych kosztów pożyczek. Dotyczyło to zwłaszcza pożyczek oferowanych na krótki okres, czyli tzw. chwilówek, gdzie koszty dla klientów są zawsze największe. Wprowadzenie nowelizacji ustawy o kredycie konsumenckim spowodowało zmianę struktury produktów oferowanych przez instytucje pożyczkowe.

Największą zmianą w strukturze sprzedanych pożyczek w 2016 r. było zmniejszenie się udziału pożyczek oferowanych na okres do 3 miesięcy i zwiększenie się udziału pożyczek oferowanych na okres powyżej roku. Udział pożyczek oferowanych na okres do 3 miesięcy w 2016 r. był najniższy od 6 lat i wynosił 13\%, podczas gdy w 2010 r. było to 23\%, a jeszcze w 2014 roku udział ten stanowił 1/3 wartości wszystkich sprzedanych produktów. Ponadto poprzednio instytucje pożyczkowe udzielały też sporo tzw. darmowych chwilówek, licząc przy tym na zyski związane z nieterminowością pożyczkobiorców. Nowelizacja ustawy ograniczyła te możliwości i ten obszar działalności przestał być opłacalny. W efekcie instytucje pożyczkowe zdecydowały się na udzielanie pożyczek na dłuższe terminy. W 2016 roku przeciętna wartość pożyczki wśród uczestników badania Konferencji Przedsiębiorstw Finansowych w Polsce osiągnęła wartość 1149 zł. W stosunku do roku 2015 jest to wzrost o $9 \%$ i jednocześnie jest to najwyższa wartość w historii analizy od 2008 roku $^{20}$. Liczba pożyczek udzielonych na okres powyżej roku w 2016 r. wynosił aż 48\% i była to wartość najwyższa od 6 lat. Zależności te zostały przedstawione na rys. 1.

\footnotetext{
${ }^{18} \mathrm{~K}$. Kondel, Skutki nowej ustawy antylichwiarskiej: 21 firm pożyczkowych zniknęto z rynku, https://crediteo.pl/news/skutki-nowej-ustawy-antylichwiarskiej (dostęp: 6.01 .2018 r.).

${ }^{19}$ Konferencja Przedsiębiorstw Finansowych w Polsce, Sektor instytucji pożyczkowych w Polsce. Raport z badania ankietowego. LATA 2008-2016, Gdańsk, kwiecień 2017, s. 27.

20 Ibidem, s. 20.
} 


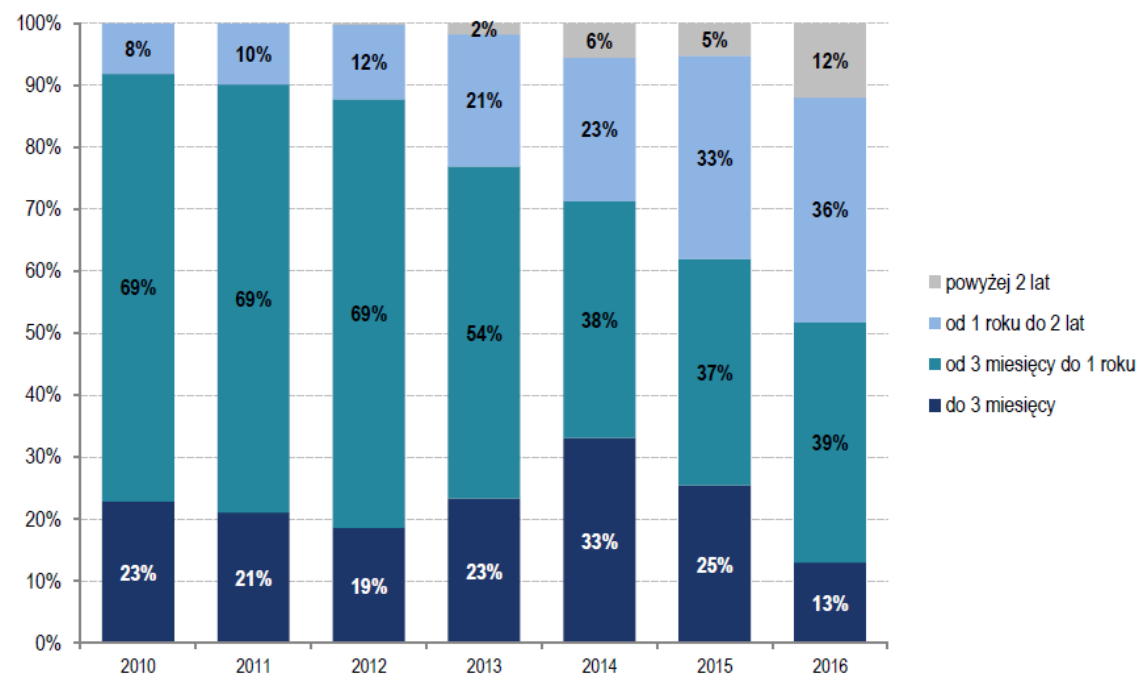

Rys. 1. Struktura udzielonych pożyczek w odniesieniu do okresu pożyczki

Źródło: Konferencja Przedsiębiorstw Finansowych, Sektor instytucji pożyczkowych w Polsce. Raport z badania ankietowego. LATA 2008-2016, Gdańsk, 2017, s. 23.

Instytucje pożyczkowe działają w segmencie z wyższym poziomem ryzyka niż banki i SKOK-i, rekompensując je sobie większymi wysokościami opłat. Wprowadzona nowelizacja ustawy o kredycie konsumenckim ogranicza te możliwości. Redukcja rolowania kosztów wymusiła na instytucjach pożyczkowych obniżenie kosztów prolongaty pożyczek na długie okresy. Same instytucje pożyczkowe zareagowały na tę sytuację i zmieniły swoją ofertę. Obecnie w porównaniu $\mathrm{z}$ okresem sprzed ustawy wejścia w życie analizowanej ustawy nowelizacyjnej koszty prolongaty są niższe, ale i możliwości prolongowania pożyczek są dużo mniejsze.

Analiza aktualnej oferty instytucji pożyczkowych pokazuje, że ograniczone zostały możliwości rolowania pożyczek. Większość instytucji pożyczkowych wprowadziła ograniczenia prolongaty pożyczki, obniżając przy tym jej koszty. W tabeli 1 na przykładzie Vivus Finance sp. z o.o. przedstawione zostały koszty związane z rolowaniem pożyczki naliczane w dniu wejścia ustawy oraz dzień, a także dwa lata po wejściu jej w życie.

Tabela 1. Opłaty za możliwość przedłużania pożyczki i jej koszty przed i po wejściu ustawy na przykładzie Vivus Finance sp. z o.o.

\begin{tabular}{|c|c|c|c|}
\hline $\begin{array}{c}\text { Długość } \\
\text { prolongaty }\end{array}$ & $\begin{array}{c}\text { Koszt } \\
(\mathbf{1 0} \text { marca 2016 r.) }\end{array}$ & $\begin{array}{c}\text { Koszt } \\
\mathbf{( 1 1} \text { marca 2016 r. })\end{array}$ & $\begin{array}{c}\text { Koszt } \\
\text { (10 marca 2018 r.) }\end{array}$ \\
\hline $7 \mathrm{dni}$ & $9,80 \%$ & $10,90 \%$ & $10,80 \%$ \\
\hline $14 \mathrm{dni}$ & $12,60 \%$ & $13,90 \%$ & $11,50 \%$ \\
\hline $30 \mathrm{dni}$ & $19,00 \%$ & $15,70 \%$ & $13,30 \%$ \\
\hline
\end{tabular}

Źródło: opracowanie własne na podstawie: https://midas24.pl/pozyczki/88-nowelizacja-ustawy (z dnia 10.03.2018); https://www.vivus.pl (dostęp: 10.03.2018 r.). 
Już następnego dnia po wejściu w życie art. 33a u.k.k. można było zauważyć wzrost kosztów przedłużania pożyczki na 7 dni, z 9,80\% na $10,90 \%$, który na zbliżonym poziomie utrzymywał się przez dwa lata. Koszt prolongaty na 14 dni wzrósł znacznie po pierwszym dniu od wprowadzenia ustawowego limitu, ale następnie spadł i w chwili obecnej jest on nawet niższy niż przed wprowadzeniem zmian. Koszty przedłużenia pożyczki na 30 dni konsekwentnie spadają w wyniku wprowadzonych regulacji, ale ograniczona jest też dostępność do takiego przedłużenia.

Od dnia obowiązywania art. 33a u.k.k., czyli od 11 marca 2016 r. część klientów ma prawo tylko do jednokrotnego przedłużenia terminu płatności, a wybrani mogą skorzystać z tej możliwości dwukrotnie. Większość instytucji pożyczkowych ograniczyła również możliwości dostępu do ,pierwszej darmowej pożyczki”, gdyż zgodnie z obecnymi przepisami nie będą one mogły naliczyć odpowiednio wysokich kosztów związanych w zaistnieniem płatności po terminie, tak aby zrekompensować sobie brak pobierania opłat w pierwszym okresie pożyczki. Zaznaczy jednak należy, że niektóre instytucje pożyczkowe zdecydowały się, głównie ze względów promocyjnych, na zachowanie jej w ofercie ${ }^{21}$. Możliwości otrzymania przez klientów pierwszej „darmowej pożyczki” oraz wydłużenia terminu spłaty pożyczki na przykładzie ofert wybranych instytucji pożyczkowych przedstawione zostały w tabeli 2 .

Tabela 2. Możliwości prolongaty terminu spłaty pożyczki na przykładzie wybranych ofert instytucji pożyczkowych (stan na dzień 24.03.2018 r.)

\begin{tabular}{|c|l|l|c|}
\hline $\begin{array}{c}\text { Nazwa } \\
\text { instytucji } \\
\text { pożyczkowej }\end{array}$ & \multicolumn{1}{|c|}{$\begin{array}{c}\text { Dostęp } \\
\text { do pierwszej pożyczki } \\
\text { za 0 zł }\end{array}$} & \multicolumn{1}{|c|}{ Dostępna oferta } & $\begin{array}{c}\text { RRSO } \\
\text { pierwszej } \\
\text { pożyczki }\end{array}$ \\
\hline $\begin{array}{c}\text { Ferratum } \\
\text { Polska } \\
\text { (EkspresKasa) }\end{array}$ & $\begin{array}{l}\text { Tak } \\
\text { (okresowo, w ramach } \\
\text { promocji) }\end{array}$ & $\begin{array}{l}\text { Od } 100 \mathrm{zł} \mathrm{do} 2000 \mathrm{zł} \\
\text { na } 15 \mathrm{i} 30 \mathrm{dni}\end{array}$ & $0 \%$ \\
\hline Hapipożyczki & Nie & $\begin{array}{l}\text { Minimalna kwota: } 800 \mathrm{zł} ; \\
\text { minimalny okres: } 3 \text { m-ce }\end{array}$ & b.d. \\
\hline Provident & $\begin{array}{l}\text { Nie } \\
\text { (okresowe promocje } \\
\text { dotyczące możliwości } \\
\text { przesunięcia płatności) }\end{array}$ & $\begin{array}{l}\text { Minimalna kwota: } 300 \mathrm{zł} ; \\
\text { minimalny okres: } 3 \text { miesiące }\end{array}$ & b.d. \\
\hline Wonga & Nie & $\begin{array}{l}\text { Minimalna kwota: } 50 \mathrm{zł} ; \\
\text { minimalny okres: } 1 \text { dzień }\end{array}$ & $\begin{array}{c}\text { Przy kwocie } \\
\text { pożyczki } 50 \mathrm{zł} \\
\text { na } 1 \text { dzień: } \\
\text { ponad } 9999 \%\end{array}$ \\
\hline
\end{tabular}

Źródło: opracowanie własne na podstawie danych ze stron internetowych instytucji pożyczkowych.

Dane zawarte w tabeli 2 wskazują na niewielki dostęp do darmowych pożyczek. Wśród czterech analizowanych ofert instytucji pożyczkowych tylko jedna zawiera możliwość otrzymania pierwszej pożyczki za 0 zł. Propozycja ta proponowana jest klientom w ramach okresowej promocji, ale nie znajduje się ona w stałej ofercie instytucji pożyczkowej. Wysokie są natomiast koszty opóźnień w spłacie tej pożyczki. W przypadku płatności po

${ }^{21}$ Informacje uzyskane podczas wywiadu z członkiem rady nadzorczej instytucji pożyczkowej. 
terminie dla pożyczki w wysokości 100 zł na 15 dni RRSO wynosi $31279 \%$, a dla pożyczki w wysokości 400 zł na 30 dni RRSO wynosi 1974\%. Okresową promocję oferuje również Provident Polska S.A.: przy pożyczce na okres 12 miesięcy istnieje możliwość bezpłatnego przesunięcia terminu spłaty o miesiąc. Są to niewielkie możliwości w porównaniu z sytuacją na rynku sprzed wprowadzenia omawianej nowelizacji.

Z tabeli 2 wynikają również wprowadzone w życie ograniczenia w pożyczaniu środków na niewielkie kwoty i krótkie terminy. Większość instytucji pożyczkowych wprowadziła minimalną kwotę i minimalny okres pożyczki. Wśród analizowanych instytucji jedynie Wonga com. nie stosuje tutaj ograniczeń, ale co jest naturalne RRSO przy małych kwotach i na krótki okres jest tutaj bardzo wysokie.

4) ograniczenie tzw. lichwy w działalności instytucji pożyczkowych przyczyniło się do wzrostu świadomości finansowej konsumentów na skutek obecnej w dyskursie publicznym tematyki zmian instytucjonalnych w sektorze instytucji pożyczkowych oraz wprowadzonego przez ustawodawcę obowiązku informowania potencjalnych pożyczkobiorców o zmianach w przepisach ustawy o kredycie konsumenckim. ${ }^{22}$ Trudno jednoznacznie oszacować, czy wejście w życie wyłącznie art. 33a u.k.k., a nie wszystkich pozostałych zmian wprowadzonych ustawą z dnia 5 sierpnia 2015 r. o zmianie ustawy o nadzorze nad rynkiem finansowym i niektórych innych ustaw zwiększyło zaufanie konsumentów do sektora instytucji pożyczkowych.

5) nie wydłużył się istotnie czas oczekiwania na udzielenie pożyczki, a także procedury wewnętrzne stosowane przez instytucje pożyczkowe w zakresie udzielania pożyczek nie zmieniły ${ }^{23}$.

\section{OCENA CHARAKTERU PRESJI NA FORMALIZACJE BADANEJ INSTYTUCJI I SPOŁECZNO-GOSPODARCZYCH EFEKTÓW JEJ ODDZIAŁYWANIA}

Deklarowanym ratio legis dodanego art. 33a do ustawy o kredycie konsumenckim było zwiększenie poziomu ochrony konsumentów korzystających z usług instytucji finansowych udzielających kredytów konsumenckich, nieobjętych obowiązkiem uzyskania zezwolenia Komisji Nadzoru Finansowego.

Wprowadzenie limitu pobieranych opłat windykacyjnych rzeczywiście uczyniło zadość temu celowi. Instytucje pożyczkowe w zakresie dochodzonych roszczeń muszą obecnie przestrzegać ograniczenia, że w przypadku, gdy łączna wysokość opłat z tytułu zaległości w spłacie kredytu, o których mowa w art. 30 ust. 1 pkt 11 u.k.k. oraz odsetek za opóźnienie naliczonych konsumentowi przekracza kwotę odpowiadającą kwocie odsetek maksymalnych za opóźnienie, o których mowa w art. $481 \S 2^{1}$ k.c., obliczonych od kwoty zaległości w spłacie kredytu, należnych na dzień pobrania tych opłat lub odsetek należy się tylko kwota opłat i odsetek odpowiadających kwocie tych odsetek maksymalnych za opóźnienie. Dotychczasowe rozwiązania normatywne w tym zakresie opierały się przede wszystkim na dyspozycji art. 30 ust. 1 pkt 11 u.k.k. - wynikającej z zasady swobody umów - umożliwiającej pobieranie przez pożyczkodawców opłat i prowizji z tytułu zaległości w spłacie

\footnotetext{
${ }^{22}$ Szerzej zob. Związek Firm Pożyczkowych, Rynek firm pożyczkowych trzy miesiące po regulacji. Wyniki i opracowanie badania, Warszawa 2016, s. 8.

${ }^{23}$ Informacje uzyskane podczas wywiadu z pracownikami instytucji pożyczkowej.
} 
pożyczki ${ }^{24}$. Powołany przepis art. 30 ust. 1 pkt 11 u.k.k. nie chronił jednak konsumentów przed obchodzeniem przez instytucje pożyczkowe przepisów o maksymalnych odsetkach za opóźnienie (481 $§ 2^{1}$ k.c.) oraz pobieraniem wspominanych opłat i prowizji w nadmiernej wysokości ${ }^{25}$.

Nie ulega więc wątpliwości, że wprowadzony limit opłat windykacyjnych zwiększył ochronę klientów instytucji pożyczkowych przed nadmiernym zadłużaniem się i wzmocnił ich pozycję procesową w przypadku dochodzenia zaległości w spłacie pożyczek. Dodatkowo wyeliminował także niejednolitość orzecznictwa sądowego zapadającego na tle art. 30 ust. 1 pkt 11 u.k.k.

Prima facie wydaje się więc, że dodanie art. 33a do ustawy o kredycie konsumenckim nie wygenerowało żadnych negatywnych konsekwencji dla konsumentów. Tak jednak nie jest. Obowiązujący limit z art. 33a u.k.k. zmusił instytucje pożyczkowe do poszukiwania nowych źródeł dochodu. W związku z tym dążąc do maksymalizacji zysków podniosły one niektóre opłaty oraz zmodyfikowały swoje oferty pożyczkowe wprowadzając ograniczenia m.in. w zakresie: możliwości dostępu do ,pierwszej darmowej pożyczki”, wyłączania możliwości jednokrotnego przedłużenia terminu płatności, a w przypadku niektórych ofert całkowitego wyeliminowania możliwości rolowania terminu spłaty zobowiązań. Stwierdzić więc można, że wprowadzenie omawianego przepisu podniosło ,ceny” niektórych produktów oferowanych konsumentom przez instytucje pożyczkowe oraz zredukowało jednocześnie część dostępnych rozwiązań umownych umożliwiających im dopasowanie zasad zwrotu długu do indywidualnej sytuacji finansowej.

Mankamentem wprowadzonych zmian jest również stosunkowo wąski zakres przedmiotowy wprowadzonego limitu opłat windykacyjnych, ponieważ dotyczy on wyłącznie umów o pożyczkę (kredyt konsumencki), która spełnia przesłanki z art. 3 ust. 1-1a u.k.k.

Co więcej, wnioskodawcy w uzasadnieniu projektu ustawy nowelizacyjnej wskazywali, iż wprowadzenie m.in. limitów w zakresie opłat windykacyjnych nie wygeneruje obciążeń czy skutków dla budżetu państwa ${ }^{26}$. Takie stwierdzenie uznać należy za dyskusyjne z uwagi na powołane wcześniej dane o liczbie zlikwidowanych instytucji pożyczkowych po wejściu w życie wspomnianej ustawy nowelizacyjnej, w tym także art. 33a u.k.k. Poza tym wprowadzony limit kosztów windykacyjnych wygenerował spadek, przynajmniej w pierwszym roku obowiązywania art. 33a u.k.k. dochodów części instytucji pożyczkowych ${ }^{27}$.

\section{PROGNOZOWANIE I FORMUŁOWANIE ZALECEŃ}

Dodanie art. 33a do ustawy o kredycie konsumenckim w kontekście powyższych wywodów pozwala przypuszczać, że dłużnym okresie czasu w związku ze zwiększeniem ochrony instytucjonalnej konsumentów zmniejszy się liczba postępowań sądowych i skarg

${ }^{24}$ Zob. T. Czech, Adekwatność wysokości opłat i prowizji bankowych w stosunku do poniesionych kosztów, „Monitor Prawa Bankowego” 2014, nr 10, s. 80 i n.

25 Tak T. Czach, Kredyt konsumencki. Komentarz, Warszawa 2017, wyd. II - LEX, art. 33a (dostęp: 19.03.2018 r.)

${ }^{26}$ Uzasadnienie projektu ustawy z dnia 5 sierpnia 2015 r. ustawy o zmianie ustawy o nadzorze nad rynkiem finansowym i niektórych innych ustaw (Dz.U. z 2015 r., poz. 1375), VII kadencja, druk sejmowy nr 3460.

27 Szerzej zob. Związek Firm Pożyczkowych, Rynek firm pożyczkowych trzy miesiace po regulacji. Wyniki i opracowanie badania, Warszawa 2016, s. 6 i n. 
do Prezesa Urzędu Konkurencji i Konsumentów w zakresie nadmiernych opłat windykacyjnych pobieranych przez instytucje pożyczkowe. Dodatkowo wzrośnie zaufanie klientów do sektora tzw. firm pożyczkowych w uwagi na większą transparentność sposobu ustalania wysokości opłat z tytułu zaległości w spłacie pożyczki.

W związku z analizowaną regulacją można sformułować następujące zalecenia badawcze oraz postulaty legislacyjne. Analizę liczby i przedmiotu postępowań sądowych oraz skarg do Prezesa Urzędu Ochrony Konkurencji i Konsumentów na tle art. 33a u.k.k. w związku z art. 30 ust. 1 pkt 11 u.k.k. można przeprowadzić przy uwzględnieniu skutków wejścia w życie przepisów art. 59aa-59ag u.k.k. wprowadzających od dnia 22.07.2017 r. ${ }^{28}$ reglamentację działalności gospodarczej prowadzonej przez instytucje pożyczkowe poprzez obowiązek jej wpisu do rejestru instytucji pożyczkowych prowadzonego przez Komisję Nadzoru Finansowego. Obecnie, stan na 17.08.2018 r., rejestr instytucji pożyczkowych obejmuje łącznie 392 instytucje funkcjonujące na rynku² .

De lege ferenda wydaje się, że limit $\mathrm{z}$ art. 33a u.k.k. w zakresie tzw. opłat windykacyjnych powinien dotyczyć także umów wskazanych w art. 4 ust. 1 oraz ust. 2 pkt 2-4 i 6 u.k.k., czyli m.in. umowy odwróconego kredytu hipotecznego, leasingu, jeśli umowa ta nie przewiduje obowiązku nabycia przedmiotu umowy przez konsumenta, a także umowy restrukturyzacyjnej.

\section{LITERATURA}

1. Chmielnicki P. (red.), Pochodzenie, tworzenie i efektywność prawa, Lexis Nexis, Warszawa 2014.

2. Czech T., Adekwatność wysokości opłat i prowizji bankowych w stosunku do poniesionych kosztów, ,Monitor Prawa Bankowego” 2014, nr 10.

3. Czech T., Kredyt konsumencki. Komentarz, Warszawa 2017.

4. Konferencja Przedsiębiorstw Finansowych w Polsce: Sektor instytucji pożyczkowych w Polsce. Raport z badania ankietowego. LATA 2008-2016, Gdańsk, kwiecień 2017.

5. Ofiarski Z., Ustawa o kredycie konsumenckim. Komentarz, Warszawa 2014.

6. Związek Firm Pożyczkowych, Rynek firm pożyczkowych trzy miesiące po regulacji. Wyniki i opracowanie badania, Warszawa 2016.

\section{PRAWODAWSTWO}

1. Ustawa z dnia 23 kwietnia 1964 r. - Kodeks cywilny (tekst jedn. Dz.U. z 2018 r., poz. 1025 ze zm.).

2. Ustawa z dnia 17 listopada 1964 r. - Kodeks postępowania cywilnego (tekst jedn. Dz.U. z 2018 r., poz. 155).

${ }^{28}$ Ustawa z 22 października 2017 r. o kredycie hipotecznym oraz o nadzorze nad pośrednikami kredytu hipotecznego i agentami (Dz.U z 2017 r., poz. 819). Jeśli instytucja pożyczkowa w dniu 22.07.2017 r. prowadziła działalność w zakresie udzielania lub dawania przyrzeczenia udzielenia kredytu konsumenckiego to może ją kontynuować, ale do dnia 22.01.2018 r. powinna złożyć wniosek o wypis do rejestru instytucji pożyczkowych prowadzonego przez Komisję Nadzoru Finansowego.

${ }^{29}$ Komisja Nadzoru Finansowego, Rejestr instytucji pożyczkowych, https://www.knf.gov.pl/ podmioty/Rejestry_i_Ewidencje/rejestr_instytucji_pozyczkowych (dostęp: 17.08.2018 r.). 
3. Ustawa z dnia 29 sierpnia 1997 r. o komornikach sądowych i egzekucji (tekst jedn. Dz.U. z 2017 r., poz. 1277).

4. Ustawa z dnia 28 lipca 2005 r. o kosztach sądowych w postępowaniach cywilnych (tekst jedn. Dz.U. z 2018 r., poz. 300).

5. Ustawa z dnia 16 lutego 2007 r. o ochronie konkurencji i konsumentów (tekst jedn. Dz.U. z 2015 r., poz. 184).

6. Ustawa z dnia 12 maja 2011 r. o kredycie konsumenckim (tekst jedn. Dz.U. z 2018 r., poz. 993 ze zm.).

7. Ustawa $\mathrm{z}$ dnia 5 sierpnia 2015 r. o zmianie ustawy o nadzorze nad rynkiem finansowym i niektórych innych ustaw (Dz.U. z 2015 r., poz. 1375).

8. Ustawa z dnia 22 października 2017 r. o kredycie hipotecznym oraz o nadzorze nad pośrednikami kredytu hipotecznego i agentami (Dz.U z 2017 r., poz. 819).

9. Uzasadnienie projektu ustawy z dnia 5 sierpnia 2015 r. ustawy o zmianie ustawy o nadzorze nad rynkiem finansowym i niektórych innych ustaw (Dz.U. z 2015 r., poz. 1375), VII kadencja, druk sejmowy nr 3460 .

\section{ORZECZNICTWO}

1. Wyrok Sądu Najwyższego z dnia 6 kwietnia 2017 r., III CSK 174/2016, LEX nr 2340584.

\section{NETOGRAFIA}

1. https://kpf.pl/rynek-pozyczkowy-zwalnia.

2. https://www.smskredyt.pl/images/kacik-klienta/20180301Umowa_pozyczki_pienieznej_SMS Kredyt.pdf.

3. Kondel K., Skutki nowej ustawy antylichwiarskiej: 21 firm pożyczkowych zniknęło z rynku, https://crediteo.pl/news/skutki-nowej-ustawy-antylichwiarskiej.

4. Komisja Nadzoru Finansowego, Rejestr instytucji pożyczkowych, https://www.knf.gov.pl/podmioty/Rejestry_i_Ewidencje/rejestr_instytucji_pozyczkowych.

\section{ANTI-USURY PROTECTION AND CHANGES ON THE MARKET OF LENDING INSTITUTIONS - SELECTED ISSUES \\ (part 2)}

The article presents an analysis of the effects of the entry into force of art. 7 point 4 of the Act of 5 August 2015 amending the Act on supervision of the financial market and certain other acts. The declared ratio legis of this change was the introduction of a limit on the so-called debt collection (art. 33a u.k.k.) and thus increasing the level of protection for consumers using the services of financial institutions providing non-bank loans. Loan institutions before the entry into force of the aforementioned art. 33a u.k.k. based on art. 30 para. 1 point 11 u.k.k. referring to the principle of freedom of contract, they collected from consumers fees and commissions for arrears in loan repayment in the amount usually exceeding the real debt collection costs. What's more, the established provision of art. 30 para. 1 point 11 u.k.k. it also did not protect consumers from circumventing the maximum interest rates for delay by loan institutions (481 $22{ }^{1}$ k.c.). 
The introduced debt collection limit offsets the asymmetry between parties to non-bank loan agreements. In addition, consumers in the event of loan institutions initiating court or out-ofcourt proceedings for overdue receivables have gained legal certainty in harmonizing the interpretation of the provisions on the amount of fees for claimed receivables. Assessment of the effects of the entry into force on 11 March 2016 art. 33a u. k.k. was carried out using the so-called research method normative set.

The paper is the second part of the presentation and included reconstruction of links between formal (legal norms) and non-formal standards, verification of the research hypotheses, assessment of the nature of the pressure on the formalization of the studied institution and socio-economic effects of its impact, and forecasting and formulating research recommendations.

Keywords: the limit of debt collection fees, arrears in loan repayment, loan institutions, consumers.

DOI: $10.7862 /$ rz.2018.hss.46

Przestano do redakcji: maj $2018 r$. Przyjęto do druku: wrzesień 2018 r. 
